\title{
Remarkably high performance of clew-like ZnO superstructure in reactive adsorption desulfurization
}

\author{
Peng Bai ${ }^{1 *}$, Bowen Liu ${ }^{1}$, Pingping $\mathrm{Wu}^{1}$, Rooh Ullah ${ }^{1}$, Wei Xing ${ }^{2}$ and Zifeng Yan $^{1^{*}}$
}

\begin{abstract}
In this study, a clew-like $\mathrm{ZnO}$ superstructure was synthesized by a copolymer-controlled self-assembly homogeneous precipitation method. $\mathrm{Ni}$ was impregnated to the clew-like $\mathrm{ZnO}$ superstructure to obtain $\mathrm{Ni} / \mathrm{ZnO}$ adsorbents. The synthesized materials were characterized by scanning electron microscopy, transmission electron microscopy, $\mathrm{N}_{2}$ sorption, $\mathrm{X}$-ray diffraction, Fourier transform infrared spectrometry, and $\mathrm{H}_{2}$-temperature programmed reduction techniques. The reactive adsorption desulfurization (RADS) performance of the adsorbents was evaluated in a fixed bed reactor using thiophene in $\boldsymbol{n}$-octane as a model fuel. Sample $\mathrm{Ni} / \mathrm{ZnO}-4 \mathrm{~h}$ exhibits a remarkably high performance with a sulfur capacity of $189.1 \mathrm{mg} \mathrm{S} \mathrm{g}^{-1}$, which is above 6 times that of the one prepared with commercial $\mathrm{ZnO}$. Characterization results show that the morphology changes from micro-clews to large solid sticks with the increase of the crystallization time. The loose and open architecture of the clew-like $\mathrm{ZnO}$ superstructure facilitates the diffusion of reactants/products, and prevents the adsorbent particles from breakage by supplying space for the volume expansion during the RADS process. The small nanoparticles in $\mathrm{ZnO}$ nanostrips result in a high sulfur adsorption capacity and also favor the dispersion of $\mathrm{Ni}$, leading to an excellent RADS performance.
\end{abstract}

Keywords: $\mathrm{ZnO}$, reactive adsorption desulfurization, nanostructure, adsorbent

\section{INTRODUCTION}

Fossil fuels contain significant quantity of organic sulfur compounds, which are the major source of detrimental $\mathrm{SO}_{x}$ and particulate pollutions [1]. The desulfurization of fossil fuels gains an increasing attention for more stringent environmental regulations and legislation on the production of clean fuels [2-4]. According to the Euro V emission standard, the sulfur content of transportation fuels is regulated to be less than $10 \mathrm{ppm}$ [5]. However, it is difficult for the traditional industrial hydrodesulfurization (HDS) process to reduce the sulfur content to such low level especially for the thiophenes and aromatic thiophenes rich fuels, due to the steric hindrance effect [6]. Furthermore, $\mathrm{H}_{2} \mathrm{~S}$ engendered during the HDS process is easy to react with olefins in gasoline to produce thiols, creating difficulties in the ultra-deep desulfurization of gasoline. Therefore, to reduce the sulfur content in gasoline below $10 \mathrm{ppm}$, it is necessary to increase the severity of HDS process, which results in the excessive saturation of olefins, causing the loss in octane value of gasoline. Alternative technologies, such as adsorption desulfurization [7-9], oxidation desulfurization $[10,11]$, extraction $[12,13]$ and bio-catalytic treatment $[14,15]$ have been developed. Among them, the reactive adsorption desulfurization (RADS) using a solid adsorbent is considered to be the most effective approach for the ultra-deep desulfurization of gasoline [16].

The origin of RADS technology could be traced back to 1920s, when some metal oxides such as $\mathrm{ZnO}, \mathrm{CaO}$ and $\mathrm{MnO}_{2}$ were found to show good adsorption performance for $\mathrm{H}_{2} \mathrm{~S}$ and later applied in the desulfurization of liquid fuel $[17,18]$. Tawara et al. [19] utilized the metal oxide supported $\mathrm{Ni}$ adsorbent for the RADS process, including $\mathrm{Ni} / \mathrm{Al}_{2} \mathrm{O}_{3}$ and $\mathrm{Ni} / \mathrm{ZnO}$. It was found that $\mathrm{Ni} / \mathrm{Al}_{2} \mathrm{O}_{3}$ catalyst exhibited a better activity than that of catalyst $\mathrm{Ni} / \mathrm{ZnO}$, while $\mathrm{Ni} / \mathrm{ZnO}$ exhibited a higher sulfur capacity due to the storage of $\mathrm{H}_{2} \mathrm{~S}$ by $\mathrm{ZnO}$, which opened ways for the design of adsorbents with high sulfur capacities. Following this pioneer work, a significant amount of efforts have been made for the development of $\mathrm{Ni} / \mathrm{ZnO}$ based adsorbents [20-22]. By studying the desulfurization mechanism of thiophenic compounds [9,22,23], the RADS process using $\mathrm{Ni} / \mathrm{ZnO}$ adsorbent was found to combine

\footnotetext{
${ }^{1}$ State Key Laboratory of Heavy Oil Processing, PetroChina Key Laboratory of Catalysis, College of Chemical Engineering, China University of Petroleum (East China), Qingdao 266580, China

${ }^{2}$ College of Science, China University of Petroleum (East China), Qingdao 266580, China

* Corresponding authors (emails: baipeng@upc.edu.cn (Bai P); zfyancat@upc.edu.cn (Yan Z))
} 
advantages of both HDS and adsorption desulfurization [24-26]. As revealed, organic sulfur compounds in the feed firstly decompose on the surface of $\mathrm{Ni}$ particles to form $\mathrm{Ni}_{3} \mathrm{~S}_{2}$ [27]. In the presence of $\mathrm{H}_{2}, \mathrm{Ni}_{3} \mathrm{~S}_{2}$ is converted to $\mathrm{H}_{2} \mathrm{~S}$ and $\mathrm{Ni}$ sites are restored to $\mathrm{Ni}^{0}$. $\mathrm{ZnO}$, as the sulfur acceptor, reacts with $\mathrm{H}_{2} \mathrm{~S}$ and is transformed to $\mathrm{ZnS}$. After regeneration in $\mathrm{O}_{2}$ atmosphere, $\mathrm{ZnO}$ is regenerated to complete a continuous RADS-regeneration cycle [28]. Bezverkhyy and co-workers [29-31] carried out a series of kinetics experiments on the RADS reactions with $\mathrm{Ni} / \mathrm{ZnO}$ based adsorbents. It is found that the rate-limiting step is the decomposition of the organosulfur compounds on $\mathrm{Ni}$ species at the beginning. With the partial sulfidation of $\mathrm{ZnO}$, the sulfur diffusion in $\mathrm{ZnO}$ becomes the rate-determining step. Based on the RADS mechanism, it is obvious that the dispersion of $\mathrm{Ni}$ species and $\mathrm{ZnO}$ morphology influence the RADS performance of adsorbents. Therefore, a $\mathrm{ZnO}$ structure that can improve the sulfur compound diffusion into $\mathrm{ZnO}$ particles and favor the nickel dispersion is desired [32]. As reported, smaller $\mathrm{ZnO}$ particles are favorable for the sulfur transfer from $\mathrm{Ni}$ to $\mathrm{ZnO}$ with lower activation energy, resulting in a higher $\mathrm{ZnO}$ conversion and a larger sulfur capacity. Besides, the smaller $\mathrm{ZnO}$ particle size would favor the $\mathrm{Ni}$ particle dispersion and enhance the interaction between $\mathrm{Ni}$ and $\mathrm{ZnO}$, resulting in the formation of $\mathrm{Ni}-\mathrm{Zn}$ alloy, which prohibits Ni particles from agglomeration [5]. Different nanostructured $\mathrm{ZnO}$ materials have been synthesized $[33,34]$. ZnO nanowires prepared by Gupta et al. [35] were tested in the RADS reaction. The adsorbent exhibits a high RADS activity and a large sulfur capacity, which is attributed to the easy sulfidation of $\mathrm{ZnO}$ nanowires and the fast sulfur transfer from $\mathrm{Ni}_{x} \mathrm{SZn}_{y}$ to $\mathrm{ZnO}$ nanowires. Besides the particle size, the morphology of $\mathrm{ZnO}$ also has a significant effect on the RADS performance of the adsorbent. Liu et al. [36] synthesized a hierarchically structured poly-crystalline $\mathrm{ZnO}$. Compared with that derived from the rod-shape $\mathrm{ZnO}$ particles, the adsorbent with the hierarchically structured $\mathrm{ZnO}$ exhibits a higher sulfur capacity.

In our previous work [37], a clew-like $\mathrm{ZnO}$ superstructure was synthesized via a copolymer-controlled selfassembly approach (CCSA). The superstructure was constituted by $\mathrm{ZnO}$ nanostrips, which wrapped each other around a common axis in a clew-twisting way. The nanostrips with a thickness of ca. $50 \mathrm{~nm}$ are consisted of nanoparticles with sizes from 50 to $100 \mathrm{~nm}$, and exhibit a porous structure with pore sizes in the range of 30-100 $\mathrm{nm}$. The intersecting and stacking nanostrips form a loose and open three dimensional (3D) archi- tecture, which is favorable for the diffusion of reactants/ products in the clews and also helps to alleviate the aggregation of adjacent nanostrips during the RADS process. Therefore, this unique superstructure may exhibit a superior RADS performance. In this work, we synthesized the $\mathrm{ZnO}$ superstructures using the CCSA approach and varied the morphology of $\mathrm{ZnO}$ by changing the crystallization time. The $\mathrm{Ni} / \mathrm{ZnO}$ adsorbents were prepared using an impregnation method. The RADS performance of adsorbents was evaluated in the reactive adsorption desulfurization of a model fuel and compared with that prepared with a commercial $\mathrm{ZnO}$. By combining characterization results from a variety of techniques, the relationship between the structural properties of adsorbents and their RADS performance was revealed.

\section{EXPERIMENTAL SECTION}

\section{Materials preparation}

The $\mathrm{ZnO}$ superstructure was synthesized through a CCSA method according to our previous procedure [37]. In a typical synthesis, $2.32 \mathrm{~g}$ of $(\mathrm{PEO})_{20}(\mathrm{PPO})_{70}(\mathrm{PEO})_{20}(\mathrm{P} 123)$ was dissolved in $60 \mathrm{~mL}$ of deionized water, followed by the addition of $7.2 \mathrm{~g}$ of urea and $5.95 \mathrm{~g}$ of $\mathrm{Zn}\left(\mathrm{NO}_{3}\right)_{2} \cdot 6 \mathrm{H}_{2} \mathrm{O}$ with continuous stirring for $30 \mathrm{~min}$. Then, the solution was transferred into a stainless steel autoclave with a Teflon liner and crystallized in an oven at $100^{\circ} \mathrm{C}$ for different times $(4,8,17$ and $48 \mathrm{~h})$. White precipitates engendered were filtered, washed for several times with deionized water and dried in an oven for $12 \mathrm{~h}$ at $80^{\circ} \mathrm{C}$. Finally, the white solids were calcined at $500^{\circ} \mathrm{C}$ for $2 \mathrm{~h}$. The white and yellowish powders before and after calcination were denoted as $\mathrm{ZCH}-x \mathrm{~h}$ and $\mathrm{ZnO}-x \mathrm{~h}$, respectively, where $x$ represented the crystallization time.

The $\mathrm{Ni} / \mathrm{ZnO}$ adsorbents (10 wt.\% Ni) were prepared by an ultrasonic-aided incipient wetness impregnation method. In a typical procedure, $0.495 \mathrm{~g}$ of $\mathrm{Ni}\left(\mathrm{NO}_{3}\right)_{3} \cdot 6 \mathrm{H}_{2} \mathrm{O}$ was dissolved in $5 \mathrm{~mL}$ of tetrahydrofuran (THF), followed by adding $1 \mathrm{~g}$ of $\mathrm{ZnO}$ into the solution. The suspension was ultrasonically dispersed at $30^{\circ} \mathrm{C}$ for $1 \mathrm{~h}$, then dried at $80^{\circ} \mathrm{C}$ overnight and calcined at $400^{\circ} \mathrm{C}$ for $1 \mathrm{~h}$. The adsorbents obtained were denoted as $\mathrm{Ni} / \mathrm{ZnO}-x \mathrm{~h}$. For comparison, a $\mathrm{Ni} / \mathrm{ZnO}$ adsorbent was prepared in the same way from a commercial $\mathrm{ZnO}$ (purchased from Sinopharm Chemical Reagent Co. Ltd) and denoted as $\mathrm{Ni}$ / $\mathrm{ZnO}-\mathrm{C}$.

\section{RADS reactions}

RADS experiments were carried out in a fixed bed reactor with a stainless steel column which had an internal di- 
mension of $8 \mathrm{~mm}$ and a length of $250 \mathrm{~mm}$. The model fuel with $3000 \mathrm{ppm}$ sulfur was prepared using thiophene as a sulfur source and $n$-octane as the solvent. Before the reaction, the reactor was flushed by ethanol for $24 \mathrm{~h}$ to clean the thiophene remaining in the system. The flushing was conducted at $150^{\circ} \mathrm{C}$ with an ethanol flow rate of $0.5 \mathrm{~mL} \mathrm{~min}^{-1}$. Then the whole system was purged with a $\mathrm{N}_{2}$ gas flow $\left(20 \mathrm{~mL} \mathrm{~min}^{-1}, 0.5 \mathrm{MPa}\right)$ at $150^{\circ} \mathrm{C}$ for $24 \mathrm{~h}$ to clean up the whole system. After that, $1 \mathrm{~g}$ of fresh adsorbent $(\mathrm{NiO} / \mathrm{ZnO})$ was put in the center of the column and reduced by $\mathrm{H}_{2}$ with a flow rate of $40 \mathrm{~mL} \mathrm{~min}^{-1}$ under $0.5 \mathrm{MPa}$ at $400^{\circ} \mathrm{C}$ for $7 \mathrm{~h}$. After the reduction, the temperature of reactor was reduced to $350^{\circ} \mathrm{C}$ and the pressure was increased to $1.0 \mathrm{MPa}$. The pre-heated model fuel was carried by $\mathrm{H}_{2}$ and flowed through the adsorbents with a liquid hourly space velocity (LHSV) of $4 \mathrm{~h}^{-1}$, and the $\mathrm{H}_{2} /$ Oil volume ratio was 400 . The liquid product was cooled in a cryogenic ice trap, periodically collected and analyzed by a gas chromatograph (Bruker $450-\mathrm{GC}$ ) coupled with a pulsed flame photometric detector (PFPD). The sulfur capacity of the adsorbents at breakthrough points of $10 \mathrm{ppm}$ (normalized by the adsorbent weight) was calculated based on [38]

$$
S=\frac{v}{1000 m_{\text {sorbent }}} \int_{0}^{t}\left(C_{0}-C_{t}\right) \mathrm{d} t
$$

where $S$ is the mass of sulfur adsorbed per gram of adsorbent $\left(\mathrm{mg} \mathrm{S} \mathrm{g}^{-1}\right), C_{0}$ is the initial sulfur concentration in the model fuel $\left(\mathrm{mg} \mathrm{L}^{-1}\right), C_{t}$ is the sulfur concentration in the effluent at time $t$ (min), $v$ is the flow rate of model fuel $\left(\mathrm{mL} \min ^{-1}\right)$, and $m_{\text {sorbent }}$ is the weight of $\mathrm{Ni} / \mathrm{ZnO}-x \mathrm{~h}$ adsorbent. The $\mathrm{ZnO}$ conversion of the adsorbent at the adsorption breakthrough point $(10 \mathrm{ppm})$ was calculated by

$$
X=0.0029 S \times 100 \%,
$$

where $X$ is the $\mathrm{ZnO}$ conversion to $\mathrm{ZnS}$ of the adsorbent at breakthrough point (10 ppm), and $S$ is the sulfur capacity at the breakthrough point (10 $\mathrm{ppm})$.

\section{Characterization of materials}

The $\mathrm{N}_{2}$ adsorption was measured on a Micromeritics TRISTAR 3000 analyzer at $77 \mathrm{~K}$. Before adsorption, samples were degassed at $300^{\circ} \mathrm{C}$ for $4 \mathrm{~h}$ under vacuum. The specific surface area of the samples was calculated by the Brunauer-Emmett-Teller (BET) method in the relative pressure range of $0.05-0.25$. The pore size distribution (PSD) curves were derived from the desorption branches using the Barrett-Joyner-Halenda (BJH) method. The total pore volumes were calculated by the adsorption amount at $P / P_{0}=0.993$. X-ray powder diffraction
(XRD) patterns were obtained by a PANalytical X'Pert diffractometer with a $\mathrm{Cu}-\mathrm{K} \alpha$ radiation generated at $35 \mathrm{kV}$ and $40 \mathrm{~mA}$. The scanning angle ranged from $20^{\circ}$ to $70^{\circ}$ with a scanning rate of $2^{\circ} \mathrm{min}^{-1}$. Average crystallite sizes of the $\mathrm{ZnO}$ crystals were calculated from the XRD patterns using Debye-Scherrer equation

$$
D=K \lambda / \beta \cos \theta \text {, }
$$

where $K$ is the Scherrer constant $(K=0.89), \lambda$ is the X-ray wavelength, $\beta$ is the peak width at the half maximum, and $\theta$ is the Bragg diffraction angle. The reducibility of samples was investigated by a hydrogen temperature programmed reduction $\left(\mathrm{H}_{2}\right.$-TPR) technique using a ChemBET 3000 TPD/TPR analyzer (Autochem II, USA). The morphology of materials was investigated by a JEOL JSM5600LV scanning electron microscope (SEM) and a JEOL JEM-2100UHR transmission electron microscope (TEM). Fourier transformed infrared (FT-IR) spectra of the adsorbents were measured on a Nicolet 6700 spectrometer coupled with a MCT liquid nitrogen cooling detector, and the samples were dehydrated at $300^{\circ} \mathrm{C}$ for $3 \mathrm{~h}$ and then subjected to pyridine adsorption for $24 \mathrm{~h}$. After adsorption of pyridine, the samples were transferred into a vacuum oven at $150^{\circ} \mathrm{C}$ for $3 \mathrm{~h}$ to remove the physisorbed pyridine. Samples were then pressed into disks with a radius $(R)$ of $1.0 \mathrm{~cm}$. The amount of Lewis acid (L acid) was quantified according to the Equation (4) described elsewhere [39]

$$
C(\text { pyridine on } \mathrm{L} \text { acid sites })=1.42 I A(\mathrm{~L}) R^{2} / W,
$$

where $C$ is the concentration of $\mathrm{L}$ acid sites $\left(\mathrm{mmol} \mathrm{g}^{-1}\right.$ catalyst), $I A$ is the integrated absorbance of $\mathrm{L}$ acid band $\left(\mathrm{cm}^{-1}\right), R$ is the radius of catalyst disk $(\mathrm{cm})$ and $W$ is the weight of the disk (mg).

\section{RESULTS AND DISCUSSION}

\section{RADS performance of adsorbents}

Figs 1, 2 show sulfur adsorption breakthrough curves and breakthrough sulfur capacities of adsorbents, respectively. As can be seen, the RADS activity of the adsorbents decreases with increasing the crystallization time of $\mathrm{ZnO}$. Amongst all samples, sample $\mathrm{Ni} / \mathrm{ZnO}-4 \mathrm{~h}$ achieves the highest breakthrough time up to $25.5 \mathrm{~h}$ with a sulfur adsorption capacity up to $189.1 \mathrm{mg} \mathrm{S} \mathrm{g}^{-1}$. Compared with $\mathrm{Ni} / \mathrm{ZnO}-4 \mathrm{~h}, \mathrm{Ni} / \mathrm{ZnO}-8 \mathrm{~h}, \mathrm{Ni} / \mathrm{ZnO}-17 \mathrm{~h}$ and $\mathrm{Ni} / \mathrm{ZnO}-48 \mathrm{~h}$ achieve a shorter breakthrough time with a decreasing breakthrough sulfur adsorption capacity. Among all samples, the adsorbent prepared with the commercial $\mathrm{ZnO}$ presents the lowest RADS activity with a breakthrough time of $4.6 \mathrm{~h}$ and a sulfur adsorption capacity of 


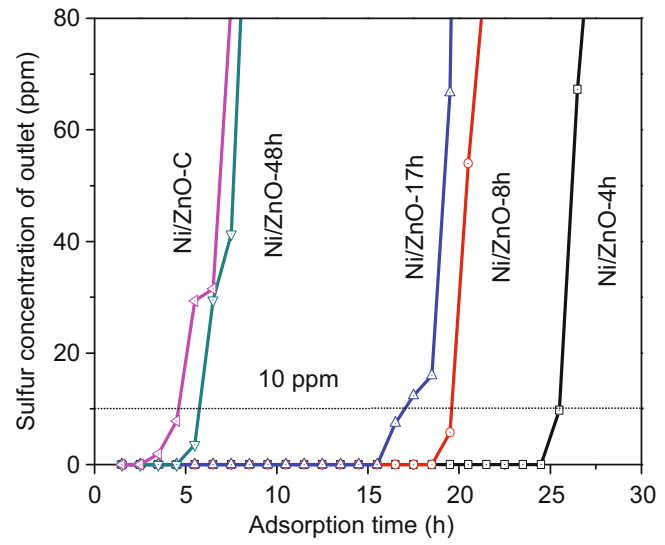

Figure 1 Sulfur adsorption breakthrough (10 ppm) curves of adsorbents.

Table $1 \mathrm{ZnO}$ conversion of different adsorbents to $\mathrm{ZnS}$ at the breakthrough point (10 $\mathrm{ppm})$

\begin{tabular}{cc}
\hline Adsorbents & ZnO conversion (\%) \\
\hline $\mathrm{Ni} / \mathrm{ZnO}-4 \mathrm{~h}$ & 54.8 \\
$\mathrm{Ni} / \mathrm{ZnO}-8 \mathrm{~h}$ & 39.6 \\
$\mathrm{Ni} / \mathrm{ZnO}-17 \mathrm{~h}$ & 33.0 \\
$\mathrm{Ni} / \mathrm{ZnO}-48 \mathrm{~h}$ & 10.6 \\
$\mathrm{Ni} / \mathrm{ZnO}-\mathrm{C}$ & 8.3 \\
\hline
\end{tabular}

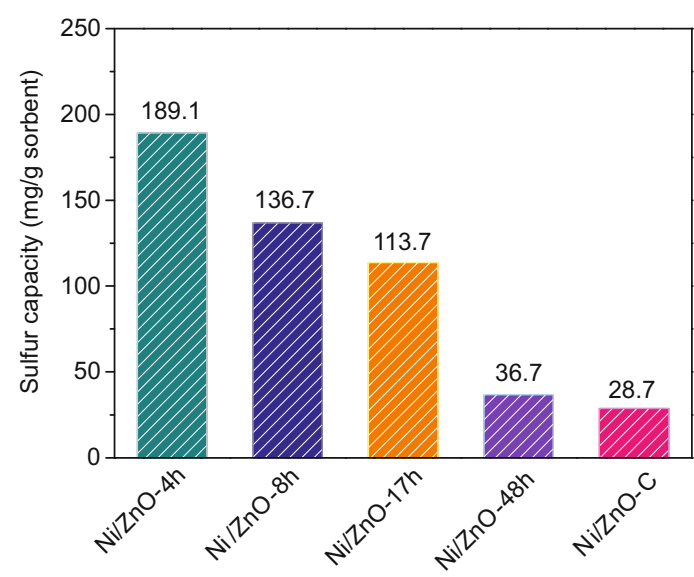

Figure 2 Breakthrough sulfur capacities of adsorbents.

$28.7 \mathrm{mg} \mathrm{S} \mathrm{g}^{-1}$, which is only $15.2 \%$ of that of $\mathrm{Ni} / \mathrm{ZnO}-4 \mathrm{~h}$. Calculated $\mathrm{ZnO}$ conversions of different adsorbents at breakthrough points are shown in Table 1 . As is seen, among all adsorbents, sample $\mathrm{Ni} / \mathrm{ZnO}-4 \mathrm{~h}$ has the highest $\mathrm{ZnO}$ conversion of $54.8 \%$. Furthermore, sample Ni/ZnO$4 \mathrm{~h}$ also shows a higher capacity than most of other $\mathrm{Ni} /$ $\mathrm{ZnO}$ adsorbents with various types of $\mathrm{ZnO}$ reported before $[35,36,40-42]$. It was widely recognized that the RADS activity and sulfur adsorption capacity were closely
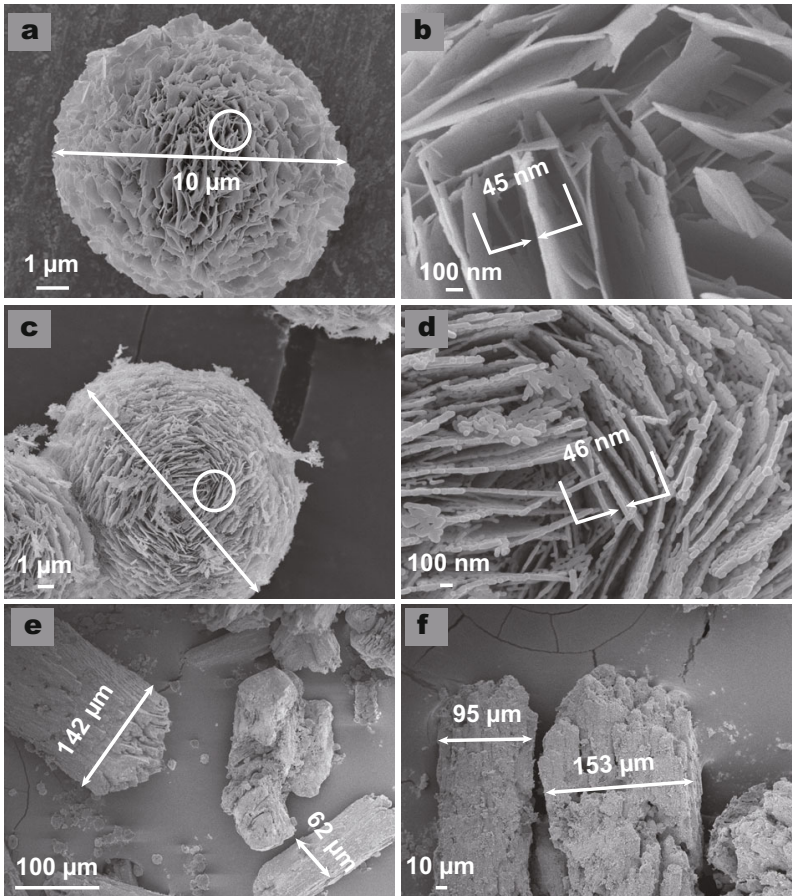

Figure 3 (a) SEM images of ZCH-4h; (b) magnified image of the circled area in image (a); (c) $\mathrm{ZnO}$ superstructure after calcining the $\mathrm{ZCH}$ precursor shown in (a); (d) magnified image of the circled area in (c); (e) $\mathrm{ZCH}-48 \mathrm{~h}$; (f) $\mathrm{ZnO}$ particles after calcining the $\mathrm{ZCH}$ precursor shown in (e).

related to the structure of $\mathrm{Ni} / \mathrm{ZnO}$ adsorbents, including the dispersion of active sites ( such as metallic $\mathrm{Ni}^{0}$ ) for $\mathrm{C}-\mathrm{S}$ bond cleavage [43], and particle size of $\mathrm{ZnO}$ for sulfur storage $[5,22]$. Compared with the commercial $\mathrm{ZnO}$ derived adsorbent, the superior RADS performance of $\mathrm{Ni} /$ $\mathrm{ZnO}-\mathrm{xh}$ adsorbent may be related to the unique morphology and nanostructure of $\mathrm{ZnO}$ prepared using the CCSA approach.

\section{SEM analysis}

Our previous results have shown that the $\mathrm{ZnO}$ precursor before calcination is a monoclinic zinc carbonate hydroxide $(\mathrm{ZCH})$ phase $\left[\mathrm{Zn}_{5}\left(\mathrm{CO}_{3}\right)_{2}(\mathrm{OH})_{6}\right]$ (JCPDS card No. 0019-1458) [37]. Fig. 3 shows the SEM images of $\mathrm{ZCH}$ precursors obtained at different crystallization times and corresponding $\mathrm{ZnO}$ materials after calcination. As can be seen, a clew-like 3D superstructure (Fig. 3a) was obtained after $4 \mathrm{~h}$ of crystallization with diameters ranging from 10 to $20 \mu \mathrm{m}$. This clew-like superstructure consists of nanostrips with a thickness of 30 to $50 \mathrm{~nm}$, and the gaps between nanostrips are around 100 to $500 \mathrm{~nm}$. After $48 \mathrm{~h}$ of crystallization, a solid rod-like morphology was obtained with a diameter of 78 to $180 \mu \mathrm{m}$. According to 
morphology evolution experiments conducted before [37], it was believed that the clew-like superstructure of $\mathrm{ZCH}$ precursor was a metastable phase during the crystallization process. In order to reduce the surface energy of the superstructure, the shrinkage of segment gaps occurred due to the coagulation of the nanostrips and the surface-smoothing effect [44], resulting in the formation of the large rod-like structures.

After calcination, the $\mathrm{ZnO}-4 \mathrm{~h}$ sample retains the same clew-like morphology as its ZCH precursor (Fig. 3c). The magnified SEM image (Fig. 3d) shows that the 3D clewlike $\mathrm{ZnO}$ superstructure consists of numerous thin $\mathrm{ZnO}$ strips with a thickness of about $50 \mathrm{~nm}$, and the nanostrips are constituted by irregular $\mathrm{ZnO}$ nanoparticles connected with small bridges, exhibiting a nanoporous motif. Compared with the image shown in Fig. 3b, after calcination, the thickness of the strips remains almost the same, while a lot of pores appear in the strips due to the decomposition of $\mathrm{ZCH}$. As the lattice parameters of $\mathrm{ZnS}$ are much higher than those of $\mathrm{ZnO}$, which result in the volume expansion of adsorbents during the RADS process [45], the existence of the small bridges and pores in $\mathrm{ZnO}$ strips is favorable for protecting the adsorbents particles from breakage by supplying space for the volume expansion. Furthermore, the unique clew-like morphology alleviates the agglomeration of $\mathrm{ZnO}$ particles due to the gaps formed by the intersecting and stacking between different nanostrips, which allow the clew-like $\mathrm{ZnO}$ superstructure to remain loose and open, facilitating the diffusion of sulfur compounds into it. By contrast, the morphology of $\mathrm{ZCH}$ synthesized with a crystallization time of $48 \mathrm{~h}$ undergoes no obvious change after calcination. The obtained $\mathrm{ZnO}$ exhibits a similar rod-like dense structure as its $\mathrm{ZCH}$ precursor. Such dense structure brings about strong diffusion resistance to sulfur transfer into the inner part of the big rods, when the surface of the big rods is covered with $\mathrm{ZnS}$ during the RADS process $[5,30]$. Therefore, the superior RADS performance of the clew-like superstructure could be partially attributed to the loose structure and small $\mathrm{ZnO}$ nanoparticles endowed by this unique morphology.

\section{XRD characterization}

XRD patterns of the $\mathrm{Ni} / \mathrm{ZnO}$ adsorbents before and after RADS are shown in Fig. 4. All fresh adsorbents contain two crystalline phases, a hexagonal wurtzite phase $(\mathrm{ZnO}$, JCPDS card No. 01-74-0534) and a nickel oxide (JCPDS card No. 03-065-6920), which is in accordance with that reported by Babich [28]. For fresh adsorbents, with increasing the crystallization time, the intensity of $\mathrm{ZnO}$
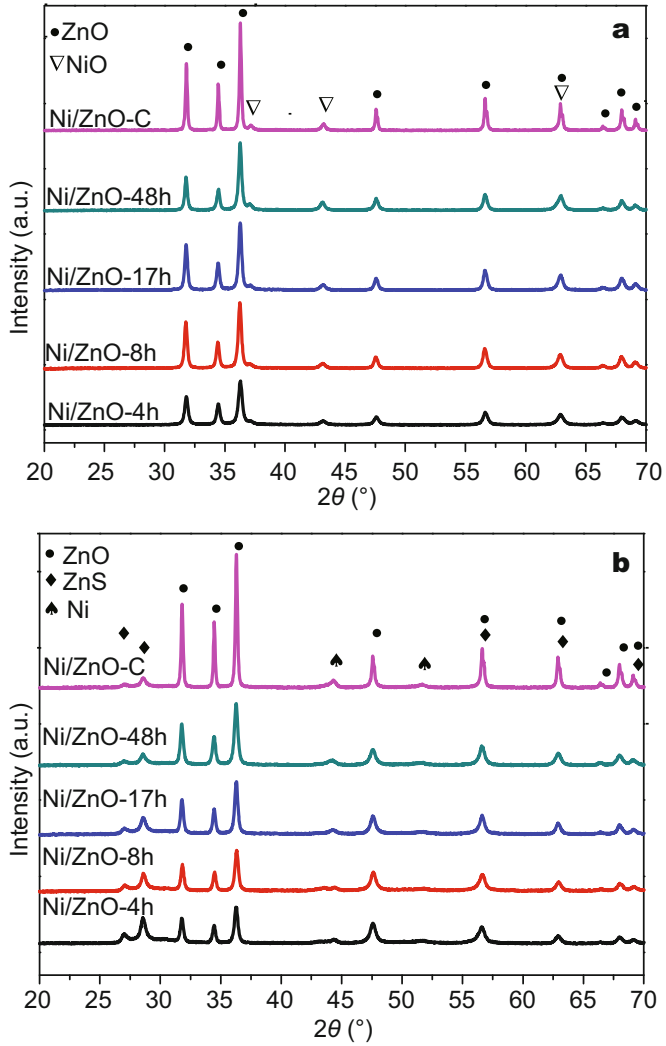

Figure 4 XRD patterns of the fresh (a) and spent (b) adsorbents.

peaks increases, and the crystallite size (shown in Table S1 (Supplementary information)) calculated by DebyeScherrer equation [46], increases from 29 to $57 \mathrm{~nm}$, which is attributed to the growth of $\mathrm{ZCH}$ crystals under hydrothermal synthesis conditions, consistent with the SEM results shown in Fig. 3.

The peak intensity of commercial $\mathrm{ZnO}$ is higher than those of synthesized samples, indicating the larger crystallite size of the commercial $\mathrm{ZnO}$ sample, which explains well the lowest RADS performance of $\mathrm{Ni} / \mathrm{ZnO}-\mathrm{C}$ among all samples. By contrast, an opposite trend is observed for $\mathrm{NiO}$, i.e., the crystallite size of $\mathrm{NiO}$ decreases with the increase of the crystallization time (Table S1), which is partially attributed to the smaller $\mathrm{ZnO}$ particle size in $\mathrm{ZnO}$ superstructures. Besides, the loose and open superstructure of $\mathrm{ZnO}-4 \mathrm{~h}$ could restrain the aggregation of $\mathrm{NiO}$ and $\mathrm{ZnO}$ particles [47] during the calcination process because of the gaps between different $\mathrm{ZnO}$ nanostrips. This result indicates that there are more metallic $\mathrm{Ni}^{0}$ sites available for the $\mathrm{C}-\mathrm{S}$ bond cleavage in adsorbents with $\mathrm{ZnO}$ synthesized at a shorter crystallization time, which accounts for the highest activity of sample 
$\mathrm{Ni} / \mathrm{ZnO}-4 \mathrm{~h}$ among all prepared adsorbents.

As shown in Fig. 4b, after RADS, all samples exhibit a cubic ZnS phase (JCPDS card No. 03-065-1691). As is clearly seen, the intensity of $\mathrm{ZnS}$ peaks follows a decreasing trend with increasing the crystallization time and the calculated crystallite sizes of $\mathrm{ZnS}$ are shown in Table $\mathrm{S} 1$. The $\mathrm{ZnO}$ of $29 \mathrm{~nm}$ in sample $\mathrm{Ni} / \mathrm{ZnO}-4 \mathrm{~h}$ is transformed to $\mathrm{ZnS}$ of $57 \mathrm{~nm}$, and the $\mathrm{ZnO}$ of $57 \mathrm{~nm}$ in sample $\mathrm{Ni} / \mathrm{ZnO}-48 \mathrm{~h}$ is converted to $\mathrm{ZnS}$ of $60 \mathrm{~nm}$.

Therefore, the sample $\mathrm{Ni} / \mathrm{ZnO}-4 \mathrm{~h}$ has the biggest crystallite size change when converting from $\mathrm{ZnO}$ to $\mathrm{ZnS}$ among all adsorbents, which is in good agreement with the previous work [48] that the smaller $\mathrm{ZnO}$ particles have a higher conversion rate during RADS process compared with larger ones. Since the diffusion of sulfur in $\mathrm{ZnO}$ particles becomes the rate-limiting step when $\mathrm{ZnO}$ particles are partially sulfidized $[31,49]$, the $\mathrm{ZnO}$ particles in $\mathrm{Ni} / \mathrm{ZnO}-4 \mathrm{~h}$ could be more easily sulfidized than those in other samples because of the smaller crystallite size, which agrees well with the calculated $\mathrm{ZnO}$ conversion results as shown in Table 1.

\section{TEM analysis}

TEM images of the fresh and spent adsorbents are shown in Fig. 5. As can be seen, Fig. 5a, b shows the microstructure of fresh sample $\mathrm{Ni} / \mathrm{ZnO}-4 \mathrm{~h}$, and two kinds of lattice fringes with different spacings are identified, attributed to $\mathrm{ZnO}$ and $\mathrm{NiO}$ crystals. The porous structure of the nanostrips shown in Fig. 3 is observed, and the loose stacking of nanoparticles facilitates the diffusion of sulfur compounds in adsorbent particles, which partially explains the excellent activity of sample $\mathrm{Ni} / \mathrm{ZnO}-4 \mathrm{~h}$ in RADS. In comparison, as seen in Fig. $5 c$, d, the particle size of $\mathrm{ZnO}$ in sample $\mathrm{Ni} / \mathrm{ZnO}-48 \mathrm{~h}$ is much larger than that in sample $\mathrm{Ni} / \mathrm{ZnO}-4 \mathrm{~h}$. The compact structure of sample $\mathrm{Ni} / \mathrm{ZnO}-48 \mathrm{~h}$ obstructs the diffusion of reactant/ product molecules in the adsorbent and restrains the $\mathrm{ZnO}$ conversion to $\mathrm{ZnS}$. TEM images of the spent sample $\mathrm{Ni}$ / $\mathrm{ZnO}-4 \mathrm{~h}$ shown in Fig. 5e, f clearly demonstrate the presence of $\mathrm{Ni}, \mathrm{ZnS}$ and $\mathrm{ZnO}$ crystals, consistent with the $\mathrm{XRD}$ results in Fig. $4 \mathrm{~b}$. The porous structure of $\mathrm{ZnO}$ nanostrips is retained after RADS and $\mathrm{ZnO}$ nanoparticles are not agglomerated or sintered to form bigger particles as that usually happens to $\mathrm{ZnO}$ nanoparticles, verifying the intrinsic advantages of the unique clew-like morphology. The voids between and within nanostrips could also protect the adsorbents particles from breakage caused by the volume expansion during $\mathrm{ZnO}$ sulfidation. It should be mentioned that $\mathrm{Ni}, \mathrm{ZnS}$ and $\mathrm{ZnO}$ appear in a single particle, which partly supports the RADS me-

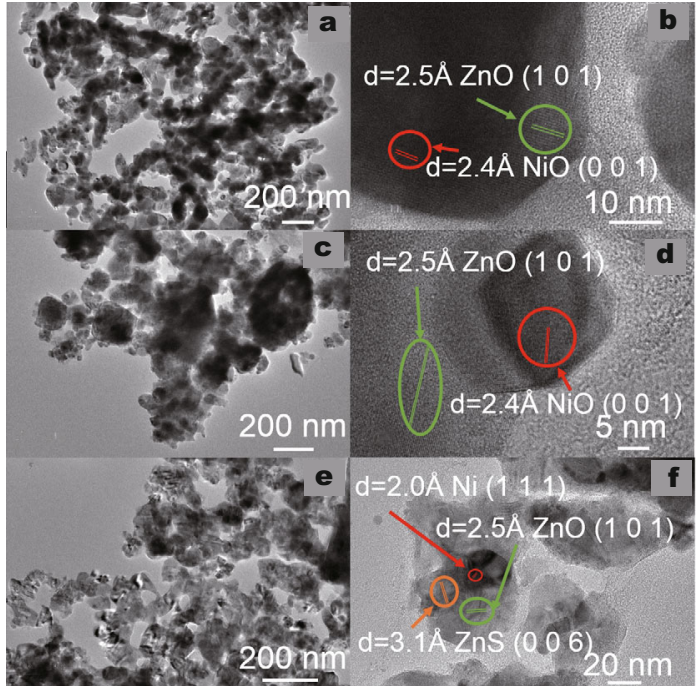

Figure 5 TEM images of the fresh $\mathrm{Ni} / \mathrm{ZnO}-4 \mathrm{~h}(\mathrm{a}, \mathrm{b})$, fresh $\mathrm{Ni} / \mathrm{ZnO}-48 \mathrm{~h}$ (c, d), and spent $\mathrm{Ni} / \mathrm{ZnO}-4 \mathrm{~h}(\mathrm{e}, \mathrm{f})$.

chanism proposed by Huang et al. [27]. During the RADS process, the thiophenic compound reacts with the active site $\mathrm{Ni}^{0}$ on the $\mathrm{ZnO}$ and produced the $\mathrm{Ni}_{3} \mathrm{~S}_{2}$. Subsequently, the sulfur in $\mathrm{Ni}_{3} \mathrm{~S}_{2}$ is converted to $\mathrm{H}_{2} \mathrm{~S}$ in the hydrogen atmosphere, which is captured by $\mathrm{ZnO}$ and converted to $\mathrm{ZnS}$. As a result, $\mathrm{Ni}$ is regenerated to $\mathrm{Ni}^{0}$ and ready for the next RADS cycle.

\section{Textual properties}

Fig. S1 shows the $\mathrm{N}_{2}$ adsorption-desorption isotherms and PSD curves of the fresh $\mathrm{Ni} / \mathrm{ZnO}$ adsorbents. All adsorbents derived from the synthesized $\mathrm{ZnO}$ materials exhibit adsorption isotherms of between type-IV and type-III, indicating the adsorbents contain both mesopores and macropores. By contrast, sample $\mathrm{Ni} / \mathrm{ZnO}-\mathrm{C}$ shows a typical non-porous structure with a very low $\mathrm{N}_{2}$ adsorption quantity, indicating the low surface area and low pore volume, which is confirmed by the results shown in Table S2. Except sample $\mathrm{Ni} / \mathrm{ZnO}-\mathrm{C}$, all samples possess an $\mathrm{H}-3$ hysteresis loop in the isotherms, evidencing that adsorbents are aggregates of plate-like particles giving rise to slit-shape pores [50], consistent with the nanostrip structure of $\mathrm{ZnO}$ as confirmed by SEM results. The PSD curves (Fig. S1b) show that all samples exhibit a bimodal pore size distribution. The sharp peak at around $3 \mathrm{~nm}$ is attributed to the tensile strength effect (TSE) and is not an indication of a real pore size distribution [51], while the larger and broad one in the range of 10-40 nm could be ascribed to the nanopores in the $\mathrm{ZnO}$ nanostrips [52]. 
In order to understand the variation in adsorbent's pore structure during the RADS process, the textural properties of the spent adsorbents were characterized and shown in Fig. S2. As can be seen, the $\mathrm{N}_{2}$ adsorption amount decreased for all adsorbents after RADS, which may be attributed to the sulfur adsorption, sintering and/or coke deposition during the RADS process. As summarized in Table S2, there are obvious declines in both surface area and pore volume for all samples after RADS. With increasing the crystallization time, the variations in surface area and pore volume generally exhibit a decreasing trend, reflecting the difference in the reactivity of adsorbents. Since the lattice parameters of $\mathrm{ZnS}$ are larger than those of $\mathrm{ZnO}$, the pore shrinkage and blockage will occur during the RADS process due to the $\mathrm{ZnO}$ volume expansion, resulting in the decrease in both surface area and pore volume. As sample $\mathrm{Ni} / \mathrm{ZnO}-4 \mathrm{~h}$ possesses the highest reactivity, it has the largest decrease in both surface area and pore volume after RADS. By contrast, sample $\mathrm{Ni} / \mathrm{ZnO}-\mathrm{C}$ exhibits the lowest variation in the pore structure due to its poor RADS activity.

\section{FT-IR analysis}

To study the structural variation of $\mathrm{ZnO}$, FT-IR spectroscopy was applied to characterize the $\mathrm{Ni} / \mathrm{ZnO}$ adsorbents before and after RADS (Fig. S3). As can be seen, FT-IR spectra of the fresh adsorbents (Fig. S3a) show a series of transmission bands at 664,881 and $1385 \mathrm{~cm}^{-1}$, which are assigned to $\mathrm{Zn}-\mathrm{O}$ stretching vibrations $[20,53,54]$. After RADS, the characteristic peaks of $\mathrm{ZnS}$ (Fig. S3b) appear in all samples at around 623, 1049 and $1090 \mathrm{~cm}^{-1}$. The band at $623 \mathrm{~cm}^{-1}$ is ascribed to the $\mathrm{Zn}-\mathrm{S}$ stretching vibration [54,55], while that at $1049 \mathrm{~cm}^{-1}$ is assigned to the resonance interaction of $\mathrm{S}^{2-}$ on the $\mathrm{ZnS}$ crystals $[20,54,56]$. And the characteristic peak at around $1090 \mathrm{~cm}^{-1}$ is attributed to the stretching mode of $\mathrm{ZnS}$ $[20,55]$. Besides the characteristic $\mathrm{Zn}-\mathrm{O}$ stretching bands, a peak at $1400 \mathrm{~cm}^{-1}$ assignable to the $\mathrm{OH}$ bending vibration in pure $\mathrm{ZnO}$ is observed for all spent samples, indicating the incomplete conversion of $\mathrm{ZnO}$ during the RADS process [53]. In a comparison, the intensity of the band at $1385 \mathrm{~cm}^{-1}$ clearly exhibits a decreasing trend with increasing the crystallization time, evidencing the higher $\mathrm{ZnO}$ conversion in adsorbents with $\mathrm{ZnO}$ synthesized at a shorter crystallization time, consistent with the results shown in Table 1.

As organosulfur compounds have strong tendency to adsorb on Lewis acid sites due to the basicity of lone electron pair, a high amount of Lewis acid sites are beneficial for the adsorption of thiophene molecules and

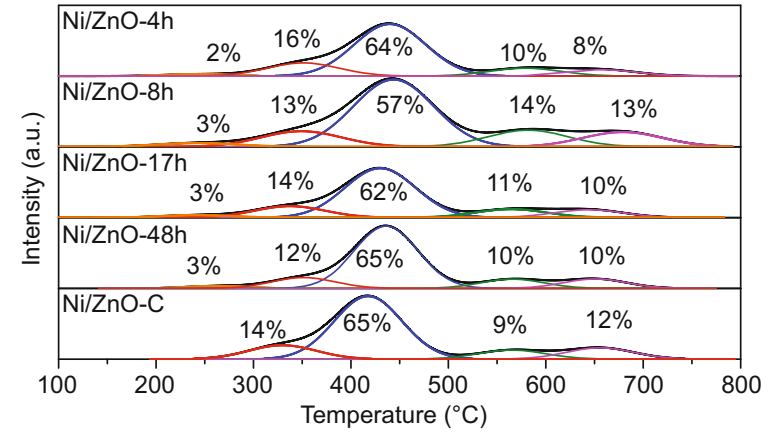

Figure $6 \mathrm{H}_{2}$-TPR profiles of the fresh adsorbents.

the subsequent $\mathrm{C}-\mathrm{S}$ bond cleavage $[57,58]$. Therefore, the pyridine adsorption FT-IR analysis of adsorbents was conducted and shown in Fig. S4. As can be seen, all samples exhibit a band at $1450 \mathrm{~cm}^{-1}$ attributed to the $19 \mathrm{bv}$ $(\mathrm{C}-\mathrm{C})$ vibration of pyridine molecules adsorbed at the Lewis acid site $[59,60]$. Among all tested adsorbents (see Table S3), sample $\mathrm{Ni} / \mathrm{ZnO}-4 \mathrm{~h}$ possesses the highest concentration of Lewis acid $\left(1.079 \mathrm{mmol} \mathrm{g}^{-1}\right)$ compared with other samples, which partially accounts for its high RADS activity.

\section{$\mathrm{H}_{2}$-TPR measurements}

Since the breakage of $\mathrm{C}-\mathrm{S}$ bonds is the rate-limiting step in the initial stage of RADS process and metal $\mathrm{Ni}^{0}$ sites are responsible for the hydrogenolysis activity [31], the chemical state and reducibility of $\mathrm{NiO}$ strongly affect the reaction rate. Hence, we characterized the adsorbents by using $\mathrm{H}_{2}$-TPR technique shown in Fig. 6 .

As seen, all samples show three $\mathrm{H}_{2}$ reduction peaks between 200 to $500^{\circ} \mathrm{C}$ in adsorbents with synthesized $\mathrm{ZnO}$, whereas only two peaks appear for the adsorbent synthesized with the commercial $\mathrm{ZnO}$. The appearance of these peaks is ascribed to the $\mathrm{Ni}^{2+} \rightarrow \mathrm{Ni}^{0}$ reduction $[27,61]$ of the nickel oxide which has different interactions with the $\mathrm{ZnO}$ [47]. The appearance of a weak peak at $250^{\circ} \mathrm{C}$ for all samples except sample $\mathrm{Ni} / \mathrm{ZnO}-\mathrm{C}$ is attributed to surface free Ni species. The broad peak at ca. $350^{\circ} \mathrm{C}$ and a large peak at ca. $450^{\circ} \mathrm{C}$ for all samples are attributed to the reduction of $\mathrm{Ni}^{2+}$ species weakly and strongly interacted with $\mathrm{ZnO}$, respectively $[62,63]$. The percentage of the $\mathrm{H}_{2}$ consumption peak at ca. $350^{\circ} \mathrm{C}$ was calculated for all samples, revealing that the ratio of the $\mathrm{NiO}$ reduced at ca. $350^{\circ} \mathrm{C}$ decreases with increasing the crystallization time and sample $\mathrm{Ni} / \mathrm{ZnO}-4 \mathrm{~h}$ has the highest amount (16\%) of weakly interacted $\mathrm{Ni}^{2+}$ species among all the samples, which implies that the open morphology and small particle sizes of $\mathrm{ZnO}$ in sample $\mathrm{ZnO}-4 \mathrm{~h}$ are favorable for the 
dispersion of easily reducible Ni species. By contrast, the strongly interacted $\mathrm{Ni}^{2+}$ species with the reduction peak at ca. $450^{\circ} \mathrm{C}$ are not able to be reduced under mild prereduction conditions $\left(400^{\circ} \mathrm{C}\right)$ [64], not contributing to the activity of adsorbents. The shoulder spanning from 500 to $750^{\circ} \mathrm{C}$ could be ascribed to the reduction of $\mathrm{NiO}$ species which are strongly attached to the $\mathrm{ZnO}$ crystals with the possible formation of Ni-Zn alloy [47]. Among all samples, $\mathrm{Ni} / \mathrm{ZnO}-4 \mathrm{~h}$ has the lowest ratio of $\mathrm{H}_{2}$ consumption in this range, also indicating the easy reducibility of $\mathrm{Ni}$ species in this sample.

\section{CONCLUSIONS}

In this work, a clew-like $\mathrm{ZnO}$ superstructure was prepared and evaluated with the RADS of a model fuel with a high sulfur concentration. Among all test samples, sample $\mathrm{Ni} / \mathrm{ZnO}-4 \mathrm{~h}$ exhibits the best performance with a $189.1 \mathrm{mg} \mathrm{S} \mathrm{g}^{-1}$ sulfur capacity, which is above 6 times that of the sample prepared with the commercial $\mathrm{ZnO}$. By combining characterization results, the superior performance of $\mathrm{Ni} / \mathrm{ZnO}-4 \mathrm{~h}$ to others is clarified to be related to the following factors: (i) small $\mathrm{ZnO}$ particles decrease the diffusion resistance of sulfur diffusion in $\mathrm{ZnO}$ crystals and promote the dispersion of $\mathrm{Ni}$; (ii) the loose and open architecture of the clew-like $\mathrm{ZnO}$ morphology enhances the diffusion of reactants/products in the adsorbent. Considering the facile synthesis route of the CCSA approach and the advantageous features of the clew-like superstructure, the $\mathrm{ZnO}$ prepared via the CCSA approach exhibits great potential in the design of industrial adsorbents with superior RADS performance.

Received 27 July 2017; accepted 26 August 2017; published online 28 September 2017

1 Saiyasitpanich P, Lu M, Keener TC, et al. The effect of diesel fuel sulfur content on particulate matter emissions for a nonroad diesel generator. J Air Waste Manage Association, 2005, 55: 993-998

2 Shi Y, Zhang X, Wang L, et al. MOF-derived porous carbon for adsorptive desulfurization. AIChE J, 2014, 60: 2747-2751

3 Zhang Y, Yang Y, Lin F, et al. Improvement of adsorptive desulfurization performance of $\mathrm{Ni} / \mathrm{ZnO}$ adsorbent by doping with Mn additive. Chin J Catal, 2013, 34: 140-145

4 Liu S, Zhang X, Zhang J, et al. $\mathrm{MoS}_{2}$ with tunable surface structure directed by thiophene adsorption toward HDS and HER. Sci China Mater, 2016, 59: 1051-1061

5 Zhang Y, Yang Y, Han H, et al. Ultra-deep desulfurization via reactive adsorption on $\mathrm{Ni} / \mathrm{ZnO}$ : the effect of $\mathrm{ZnO}$ particle size on the adsorption performance. Appl Catal B-Environ, 2012, 119-120: 13-19

6 Zhang XM, Shen BX, Hou XM, et al. Research on reactive adsorption desulfurization over metal oxides adsorbent. Energ Sources Part A-Recovery Utilization Environ Effects, 2015, 37: 209-216
7 Hou XM, Shen BX, Zhao JG. Reactive adsorption desulfurization of FCC gasoline over $\mathrm{NiO} / \mathrm{ZnO}-\mathrm{Al}_{2} \mathrm{O}_{3}-\mathrm{SiO}_{2}$ in a fixed-fluidized bed reactor. Energ Sources Part A-Recovery Utilization Environ Effects, 2014, 36: 1517-1522

8 Srivastav A, Srivastava VC. Adsorptive desulfurization by activated alumina. J Hazard Mater, 2009, 170: 1133-1140

9 Hernández-Maldonado AJ, Yang RT. Desulfurization of commercial liquid fuels by selective adsorption via $\pi$-complexation with $\mathrm{Cu}(\mathrm{I})-\mathrm{Y}$ zeolite. Ind Eng Chem Res, 2003, 42: 3103-3110

10 Gao J, Wang S, Jiang Z, et al. Deep desulfurization from fuel oil via selective oxidation using an amphiphilic peroxotungsten catalyst assembled in emulsion droplets. J Mol Catal A-Chem, 2006, 258: 261-266

11 Fang $\mathrm{Y}, \mathrm{Hu} \mathrm{H}$. Mesoporous TS-1: nanocasting synthesis with CMK-3 as template and its performance in catalytic oxidation of aromatic thiophene. Catal Commun, 2007, 8: 817-820

12 Tam PS, Kittrell JR, Eldridge JW. Desulfurization of fuel oil by oxidation and extraction. 1. Enhancement of extraction oil yield. Ind Eng Chem Res, 1990, 29: 321-324

13 Bösmann A, Datsevich L, Jess A, et al. Deep desulfurization of diesel fuel by extraction with ionic liquids. Chem Commun, 2001, 26: 2494-2495

14 Gray KA, Pogrebinsky OS, Mrachko GT, et al. Molecular mechanisms of biocatalytic desulfurization of fossil fuels. Nat Biotech, 1996, 14: 1705-1709

15 Rashtchi M, Mohebali GH, Akbarnejad MM, et al. Analysis of biodesulfurization of model oil system by the bacterium, strain RIPI-22. Biochem Eng J, 2006, 29: 169-173

16 Fan J, Wang G, Sun Y, et al. Research on reactive adsorption desulfurization over $\mathrm{Ni} / \mathrm{ZnO}-\mathrm{SiO}_{2}-\mathrm{Al}_{2} \mathrm{O}_{3}$ adsorbent in a fixedfluidized bed reactor. Ind Eng Chem Res, 2010, 49: 8450-8460

17 Jun HK, Lee TJ, Kim JC. Role of iron oxide in the promotion of $\mathrm{Zn}$-Ti-based desulfurization sorbents during regeneration at middle temperatures. Ind Eng Chem Res, 2002, 41: 4733-4738

18 Slimane RB, Abbasian J. Utilization of metal oxide-containing waste materials for hot coal gas desulfurization. Fuel Processing Tech, 2001, 70: 97-113

19 Tawara K, Nishimura $\mathrm{T}$, Iwanami $\mathrm{H}$, et al. New hydrodesulfurization catalyst for petroleum-fed fuel cell vehicles and cogenerations. Ind Eng Chem Res, 2001, 40: 2367-2370

20 Ullah R, Bai P, Wu P, et al. Superior performance of freeze-dried $\mathrm{Ni} / \mathrm{ZnO}-\mathrm{Al}_{2} \mathrm{O}_{3}$ adsorbent in the ultra-deep desulfurization of high sulfur model gasoline. Fuel Process Tech, 2016, 156: 505-514

21 Wen $\mathrm{Y}$, Wang G, Wang Q, et al. Regeneration characteristics and kinetics of $\mathrm{Ni} / \mathrm{ZnO}-\mathrm{SiO}_{2}-\mathrm{Al}_{2} \mathrm{O}_{3}$ adsorbent for reactive adsorption desulfurization. Ind Eng Chem Res, 2012, 51: 3939-3950

22 Meng $\mathrm{X}$, Huang $\mathrm{H}$, Shi L. Reactive mechanism and regeneration performance of $\mathrm{NiZnO} / \mathrm{Al}_{2} \mathrm{O}_{3}$-diatomite adsorbent by reactive adsorption desulfurization. Ind Eng Chem Res, 2013, 52: 60926100

23 Efthimiadis EA, Sotirchos SV. Reactivity evolution during sulfidation of porous zinc oxide. Chem Eng Sci, 1993, 48: 829-843

24 Tawara K, Nishimura T, Iwanami H. Ultra-deep hydrodesulfurization of kerosene for fuel cell system (Part 2). Regeneration of sulfur-poisoned nickel catalyst in hydrogen and finding of auto-regenerative nickel catalyst.. Sekiyu Gakkaishi, 2000, 43: 114-120

25 Huang L, Wang G, Qin Z, et al. In situ XAS study on the mechanism of reactive adsorption desulfurization of oil product over Ni/ZnO. Appl Catal B-Environ, 2011, 106: 26-38 
26 Wang L, Zhao L, Xu C, et al. Screening of active metals for reactive adsorption desulfurization adsorbent using density functional theory. Appl Surf Sci, 2017, 399: 440-450

27 Huang L, Wang G, Qin Z, et al. A sulfur K-edge XANES study on the transfer of sulfur species in the reactive adsorption desulfurization of diesel oil over Ni/ZnO. Catal Commun, 2010, 11: 592596

28 Babich I. Science and technology of novel processes for deep desulfurization of oil refinery streams: a review. Fuel, 2003, 82: 607631

29 Bezverkhyy I, Gadacz G, Bellat JP. Interaction of $\mathrm{Ni} / \mathrm{SiO}_{2}$ with thiophene. Mater Chem Phys, 2009, 114: 897-901

30 Bezverkhyy I, Ryzhikov A, Gadacz G, et al. Kinetics of thiophene reactive adsorption on $\mathrm{Ni} / \mathrm{SiO}_{2}$ and $\mathrm{Ni} / \mathrm{ZnO}$. Catal Today, 2008, 130: 199-205

31 Ryzhikov A, Bezverkhyy I, Bellat JP. Reactive adsorption of thiophene on $\mathrm{Ni} / \mathrm{ZnO}$ : role of hydrogen pretreatment and nature of the rate determining step. Appl Catal B-Environ, 2008, 84: 766-772

32 Zhang J, Liu Y, Tian S, et al. Reactive adsorption of thiophene on $\mathrm{Ni} / \mathrm{ZnO}$ adsorbent: effect of $\mathrm{ZnO}$ textural structure on the desulfurization activity. J Nat Gas Chem, 2010, 19: 327-332

33 Zhang Y, Kang Z, Yan X, et al. ZnO nanostructures in enzyme biosensors. Sci China Mater, 2015, 58: 60-76

34 Li LB, Wu WQ, Rao HS, et al. Hierarchical ZnO nanorod-onnanosheet arrays electrodes for efficient CdSe quantum dot-sensitized solar cells. Sci China Mater, 2016, 59: 807-816

35 Gupta M, He J, Nguyen T, et al. Nanowire catalysts for ultra-deep hydro-desulfurization and aromatic hydrogenation. Appl Catal BEnviron, 2016, 180: 246-254

36 Liu Y, She N, Zhao J, et al. Fabrication of hierarchical porous $\mathrm{ZnO}$ and its performance in $\mathrm{Ni} / \mathrm{ZnO}$ reactive-adsorption desulfurization. Pet Sci, 2013, 10: 589-595

37 Bai P, Wu P, Yan Z, et al. Self-assembly of clewlike ZnO superstructures in the presence of copolymer. J Phys Chem C, 2007, 111 9729-9733

38 Ullah R, Zhang Z, Bai $\mathrm{P}$, et al. One-pot cation-anion double hydrolysis derived $\mathrm{Ni} / \mathrm{ZnO}-\mathrm{Al}_{2} \mathrm{O}_{3}$ absorbent for reactive adsorption desulfurization. Ind Eng Chem Res, 2016, 55: 3751-3758

39 Emeis CA. Determination of integrated molar extinction coefficients for infrared absorption bands of pyridine adsorbed on solid acid catalysts. J Catal, 1993, 141: 347-354

40 Yang YX, Zhang YL, Lu W, et al. Ultra deep adsorptive desulfurization of solvent oils by Ni/ZnO adsorbent. Petrechem Tech, 2008, 3: 11

41 Ge $\mathrm{H}$, Tang $\mathrm{M}$, Wen $\mathrm{XD}$, et al. $\mathrm{Ni} / \mathrm{ZnO}$ nano sorbent for reactive adsorption desulfurization of refinery oil streams. In: Applying Nanotechnology to the Desulfurization Process in Petroleum Engineering. Pennsylvania: IGI Global, 2016, 216-239

42 Meng X, Weng HX, Shi L. Reactive adsorption of thiophene on $\mathrm{ZnNi}$ /diatomite-pseudo-boehmite adsorbents. China Pet Process Petrochem Tech, 2012, 14: 25-30

43 Petzold FG, Jasinski J, Clark EL, et al. Nickel supported on zinc oxide nanowires as advanced hydrodesulfurization catalysts. Catal Today, 2012, 198: 219-227

44 Yang HG, Zeng HC. Self-construction of hollow $\mathrm{SnO}_{2}$ octahedra based on two-dimensional aggregation of nanocrystallites. Angew Chem, 2004, 116: 6056-6059

45 Li R, Wei Z, Zhao F, et al. Investigation of localized and delocalized excitons in $\mathrm{ZnO} / \mathrm{ZnS}$ core-shell heterostructured nanowires. $\mathrm{Na}$ nophotonics, 2017, 6
46 Chung YT, Ba-Abbad MM, Mohammad AW, et al. Functionalization of zinc oxide $(\mathrm{ZnO})$ nanoparticles and its effects on polysulfone-ZnO membranes. Desalination Water Treatment, 2016, 57: 7801-7811

47 Tang M, Zhou L, Du M, et al. A novel reactive adsorption desulfurization $\mathrm{Ni} / \mathrm{MnO}$ adsorbent and its hydrodesulfurization ability compared with $\mathrm{Ni} / \mathrm{ZnO}$. Catal Commun, 2015, 61: 37-40

48 Ju F, Liu C, Meng C, et al. Reactive adsorption desulfurization of hydrotreated diesel over a $\mathrm{Ni} / \mathrm{ZnO}-\mathrm{Al}_{2} \mathrm{O}_{3}-\mathrm{SiO}_{2}$ adsorbent. Energy Fuels, 2015, 29: 6057-6067

49 Bezverkhyy I, Safonova OV, Afanasiev P, et al. Reaction between thiophene and $\mathrm{Ni}$ nanoparticles supported on $\mathrm{SiO}_{2}$ or $\mathrm{ZnO}$ : in situ synchrotron X-ray diffraction study. J Phys Chem C, 2009, 113: 17064-17069

50 Rouquerol F, Rouquerol J, Sing K. Adsorption by active carbons. In: Adsorption by Powders \& Porous Solids Principles, Methodology and Applications. Oxford: Elsevier, 1999. 237-285

51 Groen JC, Peffer LAA, Pérez-Ramırez J. Pore size determination in modified micro- and mesoporous materials. Pitfalls and limitations in gas adsorption data analysis. Microporous Mesoporous Mater, 2003, 60: 1-17

52 Zhou H, Fan T, Zhang D. Hydrothermal synthesis of ZnO hollow spheres using spherobacterium as biotemplates. Microporous Mesoporous Mater, 2007, 100: 322-327

53 Sharma R, Alam F, Sharma AK, et al. ZnO anchored graphene hydrophobic nanocomposite-based bulk heterojunction solar cells showing enhanced short-circuit current. J Mater Chem C, 2014, 2: 8142-8151

54 Rema Devi BS, Raveendran R, Vaidyan AV. Synthesis and characterization of $\mathrm{Mn}^{2+}$-doped $\mathrm{ZnS}$ nanoparticles. Pramana-J Phys, 2007, 68: 679-687

55 Trivedi MK, Tallapragada RM, Branton A, et al. Influence of biofield treatment on physical and structural characteristics of barium oxide and zinc sulfide. J Lasers Opt Photon, 2015, 2: 1000122

56 Meng W, Qi Z, Wei H, et al. Surface stoichiometry of zinc sulfide and its effect on the adsorption behaviors of xanthate. Chem Cent J, 2011, 5: 73

57 Wormsbecher RF, Kim G. Sulfur reduction in FCC gasoline. US Patent, 5525210, 1996-06-11

58 Yan $\mathrm{Z}$, Fan J, Zuo Z, et al. $\mathrm{NH}_{3}$ adsorption on the Lewis and Bronsted acid sites of $\mathrm{MoO}_{3}$ (010) surface: a cluster DFT study. Appl Surf Sci, 2014, 288: 690-694

59 Meng $\mathrm{X}$, Huang $\mathrm{H}$, Weng $\mathrm{H}$, et al. Ni/ZnO-based adsorbents supported on $\mathrm{Al}_{2} \mathrm{O}_{3}, \mathrm{SiO}_{2}, \mathrm{TiO}_{2}, \mathrm{ZrO}_{2}$ : a comparison for desulfurization of model gasoline by reactive adsorption. Bull Korean Chem Soc, 2012, 33: 3213-3217

60 Yang YL, Kou Y. Determination of the Lewis acidity of ionic liquids by means of an IR spectroscopic probe. Chem Commun, 2004, 10: 226-227

61 Kraleva E, Sokolov S, Schneider M, et al. Support effects on the properties of $\mathrm{Co}$ and $\mathrm{Ni}$ catalysts for the hydrogen production from bio-ethanol partial oxidation. Int J Hydrogen Energy, 2013, 38: $4380-4388$

62 Denis A, Grzegorczyk W, Gac W, et al. Steam reforming of ethanol over $\mathrm{Ni}$ /support catalysts for generation of hydrogen for fuel cell applications. Catal Today, 2008, 137: 453-459

63 Chandra Srivastava V. An evaluation of desulfurization technologies for sulfur removal from liquid fuels. RSC Adv, 2012, 2: 759 783 
64 Zhang $\mathrm{J}, \mathrm{Xu} \mathrm{H}$, Jin $\mathrm{X}$, et al. Characterizations and activities of the nano-sized $\mathrm{Ni} / \mathrm{Al}_{2} \mathrm{O}_{3}$ and $\mathrm{Ni} / \mathrm{La}-\mathrm{Al}_{2} \mathrm{O}_{3}$ catalysts for $\mathrm{NH}_{3}$ decomposition. Appl Catal A-General, 2005, 290: 87-96

Acknowledgements This work was supported by the Joint Funds of the National Natural Science Foundation of China and China National Petroleum Corporation (U1362202), the National Natural Science Foundation of China (51601223 and 21206195), the Fundamental Research Funds for the Central Universities (17CX05018, 17CX02056 and YCX2017039), Shandong Provincial Natural Science Foundation (ZR2012BM014), and the project sponsored by Scientific Research Foundation for Returned Overseas Chinese Scholars.
Author contributions Bai $\mathrm{P}$ conceived the idea and arranged the experiments; Liu B conducted the material synthesis and evaluated the adsorbents in RADS; Wu P, Ullah R, Xing W and Yan Z helped in the characterization of materials and data analysis. All authors contributed to the general discussion.

Conflict of interest The authors declare that they have no conflict of interest.

Supplementary information Supporting data are available in the online version of the paper.

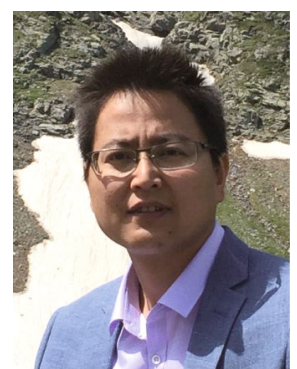

Peng Bai received his PhD from China University of Petroleum (East China) in 2008. Then, he worked in National University of Singapore as a postdoctoral research fellow. Then he worked in the Institute of Chemical and Engineering Sciences, A ${ }^{\star}$ STAR, Singapore, as a scientist. He is currently an associate professor in China University of Petroleum (East China). His research interests focus on the development of porous materials for catalytic applications.
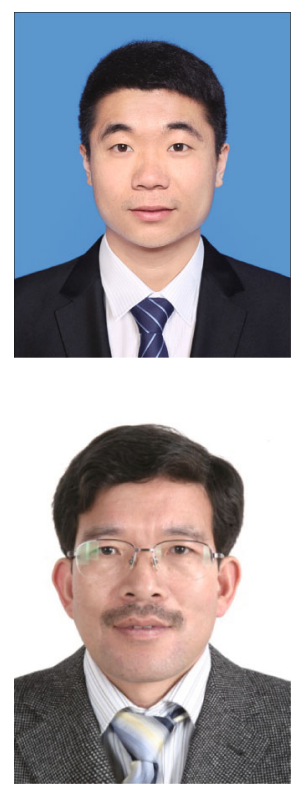

Bowen Liu is currently a master student at the College of Chemical Engineering, China University of Petroleum (East China). His research interest includes nanostructured adsorbents for reactive adsorption desulfurization.
Zifeng Yan received his PhD from Lanzhou Institute of Chemical Physics, Chinese Academy of Sciences in 1994. He is currently the Chair Professor of the State Key Laboratory of Heavy Oil Processing, PetroChina Key Laboratory of Catalysis, and a founding professor of chemical material and catalysis subjects in China University of Petroleum (East China). His research interests focus on the adsorption, catalysis and nanomaterial synthesis and application.

\title{
毛线球状 $\mathrm{ZnO}$ 超结构在反应吸附脱硫中的优异性能
}

\author{
白鹏 ${ }^{1^{*}}$, 刘博文 ${ }^{1}$, 吴萍萍 ${ }^{1}$, Rooh Ullah ${ }^{1}$, 邢伟 ${ }^{2}$, 阎子峰 ${ }^{1^{*}}$
}

摘要 本文利用共聚物控制均匀沉淀法自组装合成了一种毛线球状 $\mathrm{ZnO}$ 超结构. 通过将 $\mathrm{Ni}$ 浸渍于该氧化锌材料上制备了一系列 $\mathrm{Ni} / \mathrm{ZnO}$ 吸 附剂. 其中, 样品 $\mathrm{Ni} / \mathrm{ZnO}-4 \mathrm{~h}$ 在反应吸附脱硫中表现出极高的硫容量 $\left(189.1 \mathrm{mg} \mathrm{s}^{-1}\right)$, 是相同条件下使用普通商业 $\mathrm{ZnO}$ 制备的 $\mathrm{Ni} / \mathrm{ZnO}-\mathrm{C}$ 样 品的6倍. 毛线球状 $\mathrm{ZnO}$ 疏松开放的结构能够促进反应物/产物的扩散, 并抑制体积膨胀对吸附剂结构的破坏. 较小的 $\mathrm{ZnO}$ 颗粒在提供较高 的硫容量的同时还能促进活性组分 $\mathrm{Ni}$ 的分散, 从而导致吸附剂具有较高的反应吸附脱硫性能. 